\title{
Çölyak hastalığında serolojik, endoskopik ve histopatolojkk bulguların karşılaştırılması; tanı için öneriler
}

\author{
Comparison of serological, endoscopic, and histopathological findings in celiac disease: Recommendations \\ for diagnosis
}

(D) Ferah TUNCEL ${ }^{1}$, (D) Aslihan ALPASLAN DUMAN ${ }^{2}$

Mersin Üniversitesi Tip Fakültesi ${ }^{1}$ Tıbbi Patoloji Anabilim Dalı, Mersin, Içcel

Giresun Üniversitesi Tip Fakültesi ${ }^{2}$ Trbbi Patoloji Anabilim Dall, Giresun

Giriş ve Amaç: Dünya genelinde $\% 1$ prevalans ile görülen bir antite olan çölyak hastalığı, farklı yaşlarda ve farklı klinikler ile prezente olabilen bir hastalıktır. Tanı için klinik, serolojik ve histolojik özelliklerin korelasyonu önem arz eder. Bu çalışmanın amacı; çölyak hastalığı düşünülen olguların, serolojik, endoskopik ve histopatolojik bulgularını karşılaştırarak tanıya katkılarını belirlerken aynı zamanda tanı karmaşasına neden olabilecek parametreleri de vurgulamaktır. Gereç ve Yöntem: 01.01.2015 ve 31.12.2019 tarihleri arasında iki farklı üniversite hastanesinde çölyak hastalığı ön tanısı ile endoskopi yapılarak biyopsileri alınmış çocukluk çağında ve erişkin, toplam 204 hasta çalıșmaya dahil edilmiștir. Bu hastaların klinik, serolojik, endoskopik ve histopatolojik bulguları retrospektif olarak karşılaştırılarak aralarındaki ilişki değerlendirilmiştir. Bulgular: Olguların 130'u (\%63.7) 18 yaşın altında iken 74'ü (\%36.3) 18 yaş ve üzeriydi. Çocukluk çağı dönemine ait ortalama yaş 8.6 iken (standart sapma 4.3), erişkinde ortalama yas 43.5 (standart sapma 15.0) idi. Hastaların hastaneye en sık başvuru nedeni karın ağrısı iken (n=60, \%29.4), en sık görülen endoskopik bulgu "tarak sirtı görünümü” idi. Histopatolojik değerlendirme sonucu Marsh 2 ve üzeri şeklinde skorlanan 163 olgu (\% 79.9) çölyak hastalığını desteklemekte iken, Marsh 1 seklinde skorlanan 41 olgu (\%20.1) ise çölyak hastalığı yanı sıra ayırıcı tanıya birçok hastalığın girebileceği bir grubu temsil etmekteydi. Olguların büyük çoğunluğu serolojik olarak pozitif iken (n=125, \%82.8), 26 olguda (\%17.2) ise seroloji negatifti. Sonuç: Çalışmamızda elde ettiğimiz tüm verilerin birbirleri ile ilişkisi değerlendirilmiş ve patoloji raporlarnnda Marsh 2 ve Marsh 3 şeklinde skorlanan hastaların endoskopik bulgularının olma olasılığının Marsh 1 șeklinde skorlanan hastalara göre anlamlı oranda fazla olduğunu gördük. Tanıda altın standart olduğunu düşündügüumüz histopatolojik değerlendirme sonucunda Marsh 1 şeklinde skorlanan olgularda görülen bulguların nonspesifik bulgular olduğunun vurgulanmasinın klinisyene daha doğru bir mesaj vereceğini düşünmekteyiz.

Anahtar kelimeler: Çölyak hastalığı, seroloji, endoskopi, histopatoloji, Marsh

\section{GİRISS}

Çölyak hastalığı genetik olarak duyarlı bireylerde gluten maruziyeti ile ortaya çıkan T hücre aracılı bir enteropatidir (1). Gluten maruziyetine yönelik oluşan immünolojik yanıt kademeli olarak barsak mukozası değişikliklerine neden olur $(2,3)$. Hastalığın prevalansı dünya genelinde \%1 olarak bildirilmekle birlikte ülkeler arasında farklılıklar mevcuttur (4). Hastalığın patogenezi iyi tanımlanmış olmasına rağmen prevalansın artışı, ince barsakta otoimmüniteyi tetikleyen birtakım çevresel risk faktörlerinin göz önüne alınması gerekliliğini ortaya koymuştur (5). Duodenal biyopsi halen tanı için altın standart olarak kabul edilse de serolojik tanının yeterlili-
Background and Aims: Celiac disease, an entity with a prevalence of 1\% worldwide, is an immune disease that can be identified at various ages and in different clinics. The correlation of serological, endoscopic, and histological characteristics is critical for diagnosis. The purpose of this study is to compare the serological, endoscopic, and histopathological findings in order to determine their contribution to the diagnosis and to emphasize the parameters that may cause diagnostic uncertainty. Materials and Methods: Between January 1, 2015, and December 31, 2019, a total of 204 pediatric and adult patients, who have undergone endoscopy with a pre-diagnosis of celiac disease, were included in the study. Retrospectively, the serological, endoscopic, and histopathological findings of these patients were compared, and their relationship was evaluated. Results: While $130(63.7 \%)$ of the cases were under 18 years of age, 74 (36.3\%) of them were over 18 years of age. While the mean childhood age was 8.6 (standard deviation 4.3), the mean adult age was 43.5 (standard deviation 15.0). While the most common cause for hospital admission was abdominal pain $(n=60,29.4 \%)$, the most common endoscopic finding was "comb tooth appearance." While 163 (79.9\%) cases scored as Marsh 2 and above as a result of histopathological evaluation supported celiac disease, 41 (20.1\%) cases scored as Marsh 1 represented a group in which many diseases could be included in the differential diagnosis in addition to celiac disease. While the majority of the cases were serologically positive $(n=125,82.8 \%)$, serology was negative in $26(17.2 \%)$ cases. Conclusion: The relationship between all the data we collected in our study was analyzed, and we found that the probability of endoscopic findings in patients rated as Marsh 2 and Marsh 3 in the pathology reports was significantly higher than in patients rated as Marsh 1. We agree that emphasizing the findings in cases scored as Marsh 1 as a result of the histopathological assessment, which we believe to be the gold standard of diagnosis, as nonspecific, will give a more accurate message to the clinician.

Key words: Celiac disease, serology, endoscopy, histopathology, Marsh

ğini savunan çok sayıda çalışma mevcuttur. Serolojik tanı için spesifik olan antigluten ve doku transglutaminaz IgA (Ttg-IgA) antikor testleri mevcuttur (6). Hastaların klinik prezentasyonları çok farklılık gösterebileceği için klinik bulguların da tanıda önemi büyüktür (4). Bu nedenle tanı için klinik, serolojik ve histolojik özelliklerin korelasyonu önem arz eder. Biz bu çalışmada klinik yakınma ve bulguları nedeni ile çölyak hastalığı düşünülen olguların, serolojik, endoskopik ve histopatolojik bulgularını karşılaştırarak tanıya katkılarını belirlerken aynı zamanda tanı karmaşasına neden olabilecek parametreleri ayıklamayı hedefledik.
İletişim: Ferah TUNCEL Mersin Üniversitesi Tıp Fakültesi Tıbbi Patoloji Anabilim Dalı, 
Tablo 1. Marsh-Oberhuber evreleme sistemi (Modifiye Marsh)

$\begin{array}{lccccccc}\text { Lezyon tipi } & \text { Preinfiltratif } & \text { İnfiltratif } & \begin{array}{c}\text { İnfiltratif- } \\ \text { hiperplastik }\end{array} & \begin{array}{c}\text { Düz- } \\ \text { destrüktif }\end{array} & \begin{array}{c}\text { Düz- } \\ \text { destrüktif }\end{array} & \begin{array}{c}\text { Düz- } \\ \text { destrüktif }\end{array} & \begin{array}{c}\text { Total atrofik- } \\ \text { hipoplastik }\end{array} \\ \text { Evre } & \text { Marsh 0 } & \text { Marsh 1 } & \text { Marsh 2 } & \text { Marsh 3a } & \text { Marsh 3b } & \text { Marsh 3c } & \text { Marsh 4 } \\ \text { IEL/100 enterosit } & <40 & >40 & >40 & >40 & >40 & >40 & <40 \\ \text { Kript hiperplazisi } & - & - & + & + & + & + & - \\ \text { Villüs atrofisi } & - & - & - & \text { Hafif } & \text { Orta } & \text { Total }\end{array}$

IEL: Intraepitelyal lenfositoz.

\section{GEREÇ ve YÖNTEM}

01.01.2015 ve 31.12.2019 tarihleri arasında iki farklı üniversite hastanesinde çölyak hastalığı ön tanısı ile endoskopi yapılarak biyopsileri alınmış çocukluk çağında ve erişkin, toplam 204 hasta çalışmaya dahil edilmiştir. Olgulara ait patoloji raporları, klinik yakınma, serolojik bulgular ve endoskopik bulgular retrospektif olarak otomasyon sistemi aracılığ ile elde edilmiştir. Olgulara ait patoloji raporları düzenlenirken çölyak hastalığı tanısı için modifiye Marsh klasifikasyonu (Marsh- Oberhuber) (7), (Tablo 1) esas alınmış ve tüm olgular iki patolog tarafından değerlendirilerek raporlanmıştır. Bu klasifikasyon kullanılarak olgular; Marsh 1, Marsh 2, Marsh 3a, Marsh 3b, Marsh 3c şeklinde sınıflandırılmıştır.

\section{Etik Kurul}

Çalışmaya ait etik kurul onayı; Giresun Üniversitesi Rektörlüğü Klinik Araştırmalar Etik Kurul Başkanlığının 05.03.2020/01 karar numarası ile mevcuttur. Makalenin hazırlanmasında araştırma ve yayın etiğine uyulmuştur.

\section{İstatistiksel Analizler}

Kategorik değişkenler sayı ve yüzde cinsinden özetlenmiştir. Ilki kategorik değişken arasındaki ilişkinin incelenmesinde ki-kare testinden yararlanılmıştır. Gözelerdeki 5'ten küçük beklenen sıklık yüzdesi \%20'den fazla olduğu durumda exact testlerden yararlanılmış olup, anlamlı çıkan ilişkiler için Z testi ile iki oran karşılaştırılması yapılmıştır. Iki oran karşılaştırılmasında p değeri için Bonferroni düzeltmesi yapılmıştır. $\mathrm{P}<0.05$ istatistiksel anlamlllık düzeyi olarak kabul edilmiştir. Istatistik analizler için Statistica 13.3.1 yazılımından yararlanılmıştır.

\section{BULGULAR}

Çalışmamıza "çölyak hastalığı" ön tanısı ile endoskopik biyopsileri yapılan 204 adet hasta dahil edilmiştir. Bu olguların 130'u (\%63.7) 18 yaşın altında iken 74'ü (\%36.3) 18 yaş ve üzeriydi. Çocukluk çağı dönemine ait ortalama yaş 8.6 iken (standart sapma 4.3), erişkinde ortalama yaş 43.5 (standart sapma 15.0) idi. Kadın cinsiyet ( $\mathrm{n}=131, \% 64.2)$, erkek cinsiyete ( $n=73, \% 35.8)$ göre çoğunluktaydı. Olguların büyük çoğunluğu serolojik olarak pozitif iken (n=125, \%82.8), 26 olguda (\%17.2) ise seroloji negatifti. Hastaların hastaneye en sık başvuru nedeni karın ağrısı iken ( $n=60, \% 29.4)$, yalnızca bir hasta (\%0.5), alışılmadık bir şekilde çenede kasılma şikayeti ile başvurmuştu (Tablo 2). Bu yakınmalara eşlik eden klinik bulgular ve serolojik veriler birlikte değerlendirilerek yapılan endoskopi sonucunda en sık görülen endoskopik bulgu "tarak sırtı görünümü" iken (n=109, \%53.4), azımsanmayacak sayıda olguda endoskopik olarak gözle görülebilen herhangi bir bulgu yoktu ( $\mathrm{n}=62$, \%30.4) (Tablo 3). Histopatolojik değerlendirme sonucu Marsh 2 ve üzeri şeklinde skorlanan 163 olgu (\% 79.9) çölyak hastalığını desteklemekte iken

Tablo 2. Hastaların hastaneye başvurma yakınmaları

\begin{tabular}{lcc}
\hline Klinik & Sayı (n) & Yüzde (\%) \\
\hline Diyare & 22 & 10.8 \\
\hline Karın ağrısı & 60 & 29.5 \\
\hline Kusma & 12 & 5.9 \\
\hline Gelişme geriliği & 52 & 25.6 \\
\hline Iştahsızlık & 14 & 6.9 \\
\hline Çenede kasılma & 1 & 0.05 \\
\hline Kabızlık & 8 & 3.9 \\
\hline Kansızlık & 35 & 17.3 \\
Total & 204 & 100
\end{tabular}

Tablo 3. Hastaların endoskopilerinde görülen bulgular

\begin{tabular}{|lcc|}
\hline Endoskopik Bulgu & Sayı (n) & Yüzde (\%) \\
\hline Bulgu yok & 62 & 30.4 \\
\hline Tarak sırtı görünüm & 109 & 53.4 \\
\hline Nodülarite & 13 & 6.4 \\
\hline Tarak sırtı+nodülarite & 4 & 2.0 \\
\hline Garanüler & 10 & 4.9 \\
\hline Çorak toprak & 2 & 1.0 \\
\hline Ödem & 4 & 2.0 \\
\hline Total & 204 & 100.0 \\
\hline
\end{tabular}


(Resim 1,2,3), Marsh 1 şeklinde skorlanan 41 olgu (\%20.1) ise çölyak hastalığı yanı sıra ayırıcı tanıya bir çok hastalığın girebileceği bir grubu temsil etmekteydi (Resim 4). Çocukluk çağında tespit edilen çölyak hastalığı olgularının 128'inde boy ve vücut ağırlığı persentillerine ait veriler mevcuttu. Bu olguların boy persentilleri ve vücut ağırlı̆̆ persentillerinin her ikisi de çoğunlukla \%10'un altında kalmaktaydı (boy için; n=40, \%31.3, vücut ağırlığı için; n=34, \%26.8) (Tablo 4). Çocukluk çağı ve erişkin çölyak hastalarının tamamında, toplamda 92 olguda HLADQ2 ve HLADQ8 sonuçları mevcuttu. HLADQ2 pozitif olgular 42 adet iken HLADQ8 pozitif 10 olgumuz vardı. Çalışmamızda endoskopik bulguları, klinik, serolojik ve histopatolojik bulgular ile karşılaştırdık. Ayrıca elimizdeki tüm bu verileri birbirleri ile karşılaştırarak ilişkili parametreleri saptamayı hedefledik. Elde ettiğimiz sonuçlara göre endoskopik bulgular ile seroloji pozitifliği arasında anlamlı ilişki vardı $(\mathrm{p}=0.031)$. Seroloji pozitif olan olgularda endoskopik olarak tarak sırtı görünümünün varlığı endoskopik bulgusu olmayan gruba göre anlamlı bir şekilde yüksekti $(\mathrm{p}=0.0021)$. Histopatolojik bulgular ile Ttg-IgA değerlerini karşılaştırdığımızda da anlamlı bir ilişki olduğunu gördük. Ttg-IgA düzeyleri normalin üzerinde olan olgular sılklıkla histopatolojik olarak Marsh 2 ve üzeri şeklinde skorlanmıştı ve Marsh skor 1 olgular ile karşılaştırıldığında anlamlı bir fark mevcuttu ( $p$ <0.001). Ancak beklenenin aksine Marsh skorları ile vücut ağırlığı veya boy persentilleri arasında anlamlı bir ilişki yoktu $(\mathrm{p}=0.33, \mathrm{p}=0.41)$. Klinik bulgular ile seroloji karşılaştırıldığında anlamlı ilişki saptadık ( $<$ <0.001). Karın

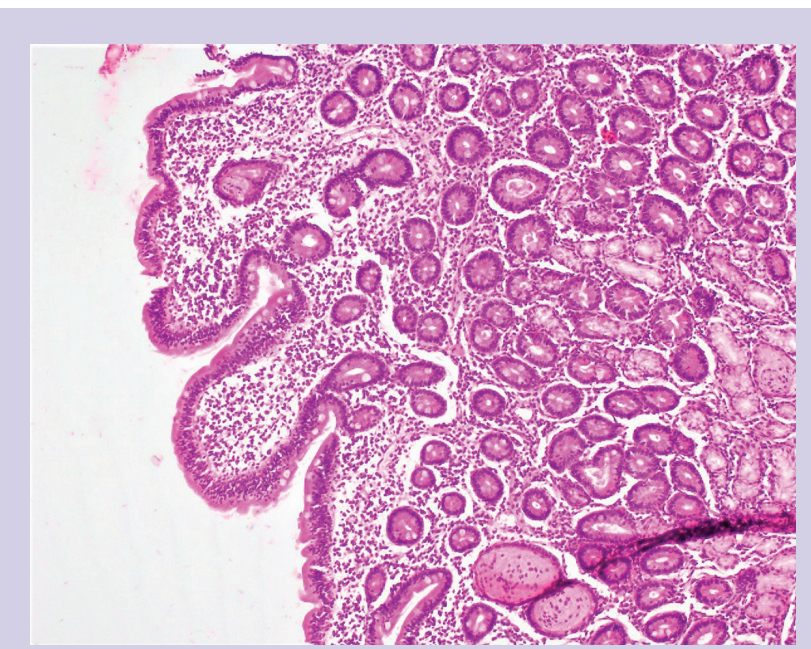

Resim 1. Çölyak hastalığı Marsh 2 şeklinde skorlanan olguya ait histopatolojik görüntü (H\&E X100).

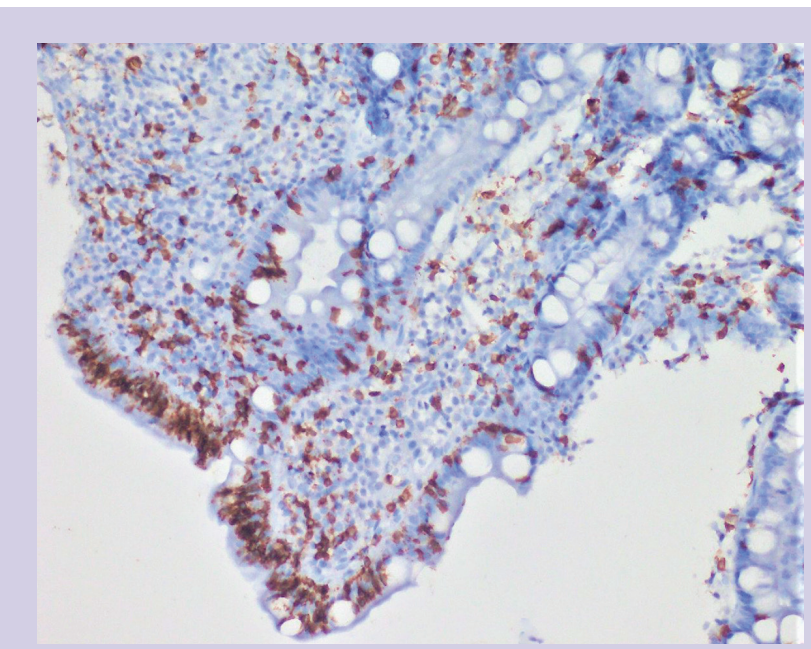

Resim 3. Çölyak hastalı̆ı Marsh 3a şeklinde skorlanan olguya ait, intraepitelyal lenfositozu gösteren immünohistokimyasal görüntü (CD3 X200).

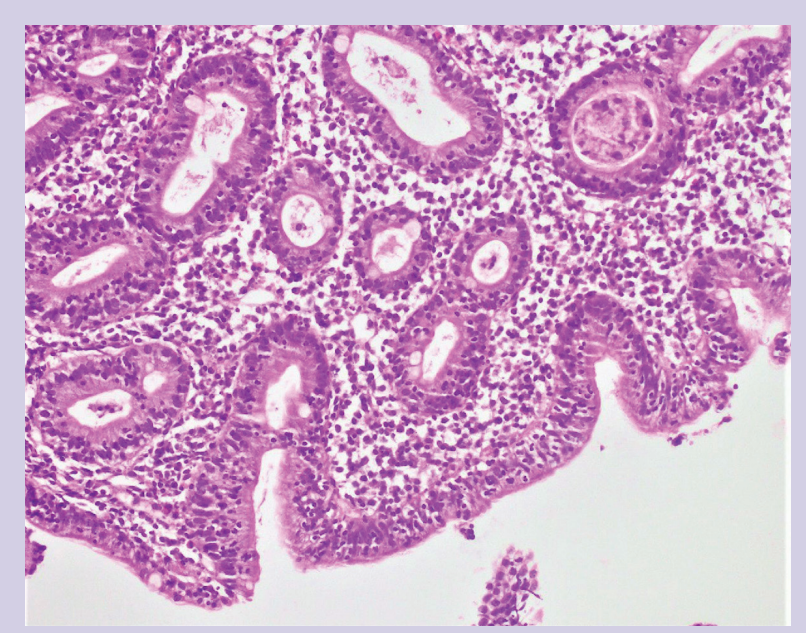

Resim 2. Çölyak hastalığı Marsh 3b şeklinde skorlanan olguya ait histopatolojik görüntü (H\&E X200).

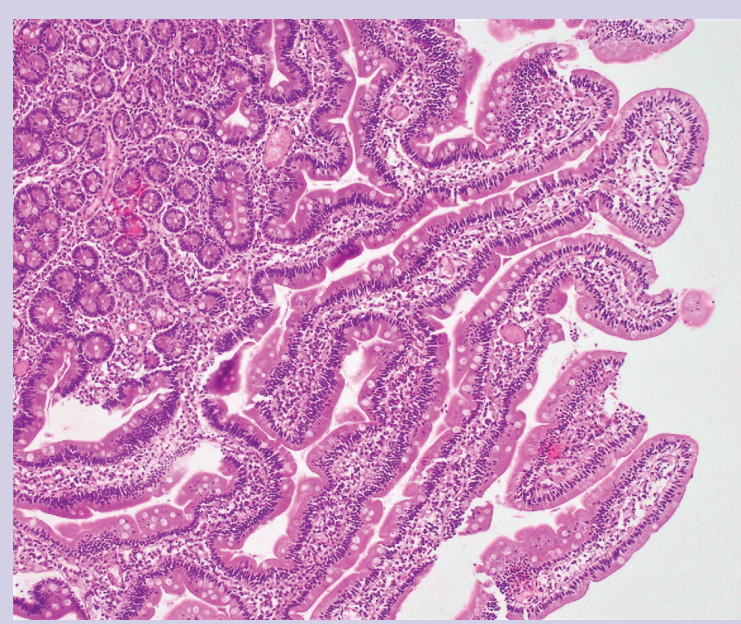

Resim 4. Çölyak hastalığı Marsh 1 şeklinde skorlanan olguya ait histopatolojik görüntü (H\&E X100). 


\begin{tabular}{|c|c|c|c|c|}
\hline \multirow[t]{2}{*}{ Persentil } & \multicolumn{2}{|c|}{ Boy } & \multicolumn{2}{|c|}{ Vücut Ağırlığı } \\
\hline & Sayı (n) & Yüzde (\%) & Sayı (n) & Yüzde (\%) \\
\hline$<10$ & 40 & 31 & 34 & 26.8 \\
\hline $10-24$ & 12 & 9.4 & 30 & 23.6 \\
\hline $25-49$ & 29 & 22.7 & 19 & 15.0 \\
\hline $50-74$ & 25 & 19.5 & 22 & 17.3 \\
\hline $75-89$ & 16 & 12.5 & 14 & 11.0 \\
\hline $90-100$ & 6 & 4.7 & 8 & 6.3 \\
\hline Total & 128 & 100.0 & 127 & 100.0 \\
\hline
\end{tabular}

ağrısı veya gelişme geriliği şikayeti ile kliniğe başvuran olguların seroloji pozitifliği diyare şikayetiyle başvuranlara göre anlamlı bir şekilde yüksekti ( $\mathrm{p}<0.001$ ). Endoskopik bulgular ile histopatolojik Marsh skorlarını karşılaştırdığımızda tarak sırtı görünümü Marsh skor 2 ve üzeri şeklinde değerlendirilen olgularda saptanırken Marsh 1 şeklinde değerlendirilen yalnızca 2 olguda mevcuttu. Bu ilişki istatistiksel olarak anlamlıydı ( $\mathrm{p}<0.001$ ) [Odds ratio $(\mathrm{OR})=46.57$, güven aralığ 1 (GA) 10.54-205.67]. Granüler görünüm ( $\mathrm{p}=0.03$ ) ve nodülarite $(\mathrm{p}=0.03)$ de Marsh skorları ile ilişkili bulunurken ödem ve endoskopik bulgu görülmemesi durumunun Marsh skorları ile ilişkisi anlamlı değildi. Sadeleştirilmişş şekliyle; Marsh skor 2 ve üzeri şeklinde skorlanan 163 olgunun 131 (\%79.6) tanesine endoskopik bulgu da eşlik ederken, Marsh 1 olarak skorlanan 41 olgunun yalnızca 12 (\%29.3) tanesinde endoskopik bulgu görülmüştü. Bu durum Marsh 2 ve üzeri şeklinde skorlanan olgularda endoskopik bulgu olma olasilığının Marsh l'e göre 9.59 kat daha yüksek olduğunu göstermekteydi $(\mathrm{GA}=4.4263-20.79, \mathrm{p}<0.001)$.

\section{TARTISSMA}

Dünya genelinde \%1 prevalans ile görülen bir antite olan çölyak hastalı̆̆ı, farklı yaşlarda ve farklı klinikler ile prezente olabilen bir hastalıktır (8). Erişkinler ile kıyaslandığında, çocukluk çağında daha sık görülmektedir (9). Bizim sonuçlarımıza baktı̆ııızda da klinik, endoskopik ve histopatolojik olarak çölyak hastalığı tanısı konfirme edilen olgularımızın büyük çoğunluğu literatür ile uyumlu bir şekilde çocukluk çağındaydı ( $\mathrm{n}=130, \% 63.7)$.

$\mathrm{Bu}$ hastalar çok farklı klinik prezentasyon ile karşımıza çıkabileceği için hastaların yakınmaları konusunda geniş bir spektruma hakim olmak gereklidir. Bizim hastalarımızda en sık gördüğümüz yakınmaları karın ağrısı iken ( $\mathrm{n}=60, \% 29.4)$, hastalarımızın diyare, kusma, iştahsızlık, kabızlık gibi gastrointestinal semptomlar yanı sıra, anemi, gelişme geriliği ve çenede kasılma gibi non-spesifik şikayetler ile de başvurduk- larını gördük. Literatüre baktı̆̆ımızda ise en sık görülen yakınma ile ilgili farklı veriler sunulmuştu. Anemi $(4,6)$, kronik diyare ve karın ağrısının (9) en sık semptom olduğunu bildiren çalışmalar olduğu gibi diyare gibi bilindik şikayetler yanı sıra ekstraintestinal yakınmalara da dikkat çeken çalışmalar mevcuttur. Çölyak hastalığı gastrointestinal ve ekstraintestinal semptomların görülebileceği çok geniş yelpaze ile prezente olan bir hastalıktır. Çocukluk döneminde; ishal, gelişme geriliği, boy kısalığı ön planda iken anoreksia, kas erimesi, apati, abdominal distansiyon, irritabilite, kusma ile de hasta başvurabilir.

Çocukluk döneminde çölyak hastalığının boy kısalığı veya gelişme geriliğine neden olabileceği bilinmektedir. Çalışmamızda, Marsh skorları ile vücut ağırlığı veya boy persentilleri arasında anlamlı bir ilişki yoktu $(\mathrm{p}=0.33, \mathrm{p}=0.41)$. Bu durum bize, hastaların erken dönemde değil, gecikmeli olarak hastaneye başvurmasından kaynaklanıyor olabileceğini düşündürdü. Histopatolojik olarak farklı skorlara sahip olan hastaların klinik olarak uzun süreli hastalığa maruziyeti Marsh skorları ile vücut ağıllığı veya boy persentilleri arasında anlamlı bir ilişki olmamasını açıklayabilir. Akla gelen bir başka durum ise; histopatolojik olarak farkllılı gösteren olguların kliniğe boy ve vücut ağırlığı parametrelerinde benzer şekilde yansıyor olabileceğidir. Erişkin dönemde ise inatçı ishal, halsizlik, kilo kaybı ön plandadır (10). Bunun yanı sıra bazı çalışmalarda ise kronik konstipasyonun tek yakınma olabileceği bildirilmektedir (11). Klinik yakınmalar bu kadar çeșitlilik gösterebildiğine göre tanı için klinik, serolojik, endoskopik ve histopatolojik bulguların korele edilmesi esastır (10).

Çalışmamızda çölyak hastalığı kuşkusu ile endoskopi yapılan olgularda en sık görülen endoskopik bulgunun tarak sirtı görünümü olduğunu saptadık ( $n=109, \% 53.4)$. Endoskopik bulgular ile histopatolojik değerlendirme sonucunda elde ettiğimiz Marsh skorları arasındaki ilişki anlamlıydı (p $<0.001$ ). Duodenal biyopsinin ve histopatolojik tanının altın standart olduğunu savunan çok sayıda çalışma mevcuttur ve bu çalışmalar aynı zamanda tanı için doğru olanın klinik, serolojik, endoskopik ve histopatolojik korelasyon olduğunu savunmaktadır $(2,4,6,10)$. Son yıllarda tanı için yeni yaklaşımlar da öne çıkmaktadır. "Biyopsi olmaksızın tanı" yaklaşımı hızla gündeme gelmekteyken (12-15) Kanada'da yapılan bir çalışmada yazarlar; serolojik tanı $(n=40)$ ve biyopsi ile tanı konulan ( $\mathrm{n}=48$ ) olguların bir yıllık takibi sonrasında çölyak hastalığı yakınma ve bulgularının gelişimi açısından farklılık görmediklerini bildirmiş ve bu nedenle serolojik tanının yeterliliğini savunmaktadırlar (16). Bizim olgularımıza baktığımızda ise yakınma ve endoskopik bulguları ile çölyak hastalı̆̆ı düşünülen hastalarımızın 15l'inin serolojik sonuçları mevcuttu. Bunların 125'inin (\%82.8) serolojisinin pozitif olduğunu gördük. Seroloji negatif olan hastalar ise azınlıktaydı $(n=26, \% 17.2)$. Seroloji pozitif olan 125 olgunun 120 tanesi 
(\%96) histopatolojik değerlendirme sonucunda; Marsh skor 2 ve Marsh skor 3 olarak raporlanmıştı ve yalnızca 5 tanesi (\%4) Marsh skor 1 şeklinde raporlanmıştı. Marsh skor 1 şeklinde raporlanan ve seroloji sonucu da mevcut olan toplam 14 olgunun ise büyük çoğunluğu seroloji negatif iken ( $n=10$, \%71.4), 4'ünde seroloji pozitifti (\%28.6). Elde ettiğimiz sonuçlara göre Marsh skorları ile seroloji arasında istatistiksel olarak anlamlı bir ilişki mevcuttu ( $\mathrm{p}<0.001)$.

Bütün bunlara rağmen biz çölyak hastalığı tanısının klinik, endoskopik, serolojik ve histopatolojik korelasyon ile konulması gerektiğini savunmaktayız. Korelasyonun önemini vurgulama nedenimiz ise; histopatolojik değerlendirme sonucunda "Çölyak Hastalığı Marsh 1 ile uyumlu olabilir" şeklinde raporlanmış 41 olgumuz olduğunu gördük (\%20.1). Ancak dikkat edilmesi gereken nokta, intraepitelyal lenfositozun çölyak hastalığı dışında başka birçok antitede de görülebilen bir bulgu olduğudur. Literatürde 2772 olgudan oluşan bir çalışmada endoskopi yapılma nedeninin sıklıkla karın ağrısı (\%38), çölyak hastalığı serolojisinin pozitif olması (\%32) ve kusma (\%14) olduğu bildirilmektedir. Ancak endoskopik biyopsi sonucunda ise olguların 352'sinde duodenit tespit edilmiş ve duodenitin en sık nedeni çölyak hastalığı (\%32) olmakla birlikte, Crohn hastalığı (\%13), Helicobacter pylori enfeksiyonu (\%6), ülseratif kolit (\%3)'in de duodenite neden olabileceği vurgulanmaktadır. Bu tanıların her birinde de intraepitelyal lenfositozun görülebileceği belirtilmiştir (17). Ayrıca çölyak hastalığına benzer mukoza değişiklikleri yapan hastalıklar içerisinde; geçici gluten intoleransı, geçici besine duyarlı enteropatiler, inek sütü duyarlılığı, soya ve diğer besin proteinlerine intolerans, gastroenterit ve postenterit sendromları, eozinofilik enteropati, giardiazis, otoimmün enteropati, mikrovillus atrofisi, kazanılmış hipogamaglobulinemi, birincil bağışıklık yetmezliği, bakteriyel aşırı üreme, protein enerji malnütrisyonu, ince barsak lenfoması da akla gelmelidir (10). Bizim olgularımızda patoloji raporlarında Marsh 2 ve Marsh 3 şeklinde skorlanan hastaların endoskopik bulgularının olma olasılı̆̆ının Marsh 1 şeklinde skorlanan hastalara göre 9.59 kat daha fazla olduğunu gördük.

\section{KAYNAKLAR}

1. Green PH, Cellier C. Celiac disease. N Engl J Med 2007;357:1731-43.

2. Belei O, Dobrescu A, Heredea R, et al. Histologic recovery among children with celiac disease on a gluten-free diet. A long-term follow up single center experience. Arch Med Sci 2018;14:94-100.

3. Tuncel F, Bozkurt F, Gulseren A, Usta Y. The incidence of and relationship between celiac disease and Helicobacter pylori gastritis in childhood. Endoskopi 2019;27:16-9.

4. Semwal P, Gupta RJ, Sharma R, Garg K. Comparision of endoscopic and histological findings between typical and atypical celiac disease in children. Pediatr Gastroenterol Hepatol Nutr 2018;21:86-92.

5. Smyk DS, Koutsoumpas AL, Mytilinaiou MG, et al. Helicobacter pylori and autoimmune disease: cause or by stander. World J Gastroenterol 2014;20:613-29.
Çölyak hastalığının histopatolojik tanısında kullanılan farklı klasifikasyonlar mevcuttur. 1992 yllında kullanılmaya başlanılan Marsh klasifikasyonu, 1999 yılında revize edilerek Marsh-Oberhuber kalsifikasyonu adını almıştır $(7,18) .2005$ yllında önerilen Corazza klasifikasyonunda ise bulgular, intraepitelyal lenfosit artışı ile birlikte (>25/100 enterosit) non atrofik (grade A) ve atrofik (grade B) şeklinde ayrilarak kısmen sadeleştirilmiş ve grade B de kendi içerisinde villus/kript oranı ve villus içerip içermemesine göre B1 ve B2 şeklinde alt gruplara ayrılmıștır (19). 2010 yllında önerilen Ensari klasifikasyonunda ise bulgular üçe ayrlarak tip 1; intraepitelyal lenfositozun eşlik ettiği normal villus yapısı olarak tanımlanmıştır. Tip 2; intraepitelyal lenfositoz, kript hiperplazisi ve villuslarda kısalma içermektedir. Tip 3 ise intraepitelyal lenfositoz, kript hiperplazisi ve tam olarak düzleşmiş mukoza şeklinde tanımlanmıştır. Ayrıca bu klasifikasyonda vurgulanan bir başka konu ise intraepitelyal lenfositlerin dağılım paterninin sayısından daha önemli olduğudur (20). Biz çalışmamızda olgularımızı raporlarken Marsh-Oberhuber kalsifikasyonunu esas aldık. Çölyak hastalığı tanısı için gerekli olan Marsh klasifikasyonunun patoloji raporlarının tümünde yer alması gerektiğini düşünmekteyiz. Ancak; Marsh 1 şeklinde skorlanan olgularda görülen bulgular ile çölyak hastalığı işaret edilmeden, bu bulguların nonspesifik bulgular olduğunun vurgulanmasının klinisyene daha doğru bir mesaj vereceğini düşünmekteyiz. Marsh 2 ve Marsh 3 şeklinde skorlanan olgularda ise klinik, serolojik ve endoskopik korelasyon önerilerek "çölyak hastalığı"na tanısal destek verilmelidir. Literatürde çok sayıda çalışmanın ve metaanalizlerin de bildirdiği üzere çölyak hastalığının tanısında endoskopik biyopsilerin değerlendirilmesi ve histopatolojik tanı klymetlidir (21-24). Biz de altın standart olduğunu düşündügüumüz histopatolojik tanı ile, doğru olguların ayırtedilmesi sağlanılarak, tedaviye yanıtın da artacağını düşünmekteyiz.

**Çalışmanın istatistiksel analizlerini yapan Dr. Öğretim üyesi Didem Derici Yıldırım'a teşekkürlerimizi sunarız.

\section{'Tüm yazarlar herhangi bir çıkar çatışması olmadığını ka- bul ederler."}

6. Kalhan S, Joseph P, Sharma S, et al. Comparative study of histopathological Marsh grading with clinical and serological parameters in celiac iceberg of North India. Indian J Pathol Microbiol 2011;54:279-83.

7. Oberhuber G, Granditssch G, Vogelsang H. The histopathology of coeliac disease: time for a standardized report scheme for pathologists. Eur J Gastroenterol Hepatol 1999;11:1185-94

8. Rosa RM, Ferrari Mde L, Pedrosa MS, et al. Correlation of endoscopic and histological features in adults with suspected celiac disease in a referral center of Minas Gerais, Brazil. Arq Gastroenterol 2014;51:290-6.

9. Poddar U. Pediatric and adult celiac disease: similarities and differences. Indian J Gastroenterol 2013;32:283-8.

10. Yönal O, Özdil S. Çölyak hastalığı. Güncel Gastroenteroloji 2014;18:93100. 
11. Akman S, Sahaloğlu O, Dalkan C, Bahçeciler NN, Arıan C. Is celiac disease misdiagnosed in children with functional constipation? Turk J Gastroenterol 2018;29:210-4.

12. Riznik P, Márta B, Bódi P, et al. The use of biopsy and "No-biopsy" approach for diagnosing paediatric coeliac disease in the Central European Region. Gastroenterol Res Pract 2019;11:1-6.

13. Werkstetter KJ, Korponay-Szabó IR, Popp A, et al. Accuracy in diagnosis of celiac disease without biopsies in clinical practice. Gastroenterology 2017;153:924-35.

14. Herrod PJJ, Lund JN. Random duodenal biopsy to exclude coeliac disease as a cause of anaemia is not cost-efective and should be replaced with universally performed pre-endoscopy serology in patients on a suspected cancer pathway. Tech Coloproctol 2018;22:121-4.

15. Roca M, Donat E, Marco-Maestud N, et al. Efficacy study of anti-endomysium antibodies for celiac disease diagnosis: A retrospective study in a Spanish Pediatric Population. J Clin Med 2019;8:2179.

16. Rajani S, Huynh HQ, Shirton L, et al. A Canadian study toward changing local practice in the diagnosis of pediatric celiac disease. Can J Gastroenterol Hepatol. 2016;2016:6234160.

17. Alper A, Hardee S, Rojas-velasquez D, et al. Prevalence, clinical, endoscopic and pathological features of duodenitis in children. J Pediatr Gastroenterol Nutr 2014;62:314-6.
18. Marsh MN. Gluten, major histocompatibility complex, and the small intestine A molecular and immunobiologic approach to the spectrum of gluten sensitivity ('celiac sprue') Gastroenterology 1992;102:330-54.

19. Corazza GR, Villanacci V. Coeliac disease. J Clin Pathol 2005;58:573-4.

20. Ensari A. Gluten-sensitive enteropathy (celiac disease): controversies in diagnosis and classification. Arch Pathol Lab Med 2010;134:826-36.

21. McCarty TR, O'Brien CR, Gremida A, Ling C, Rustag T. Efficacy of duodenal bulb biopsy for diagnosis of celiac disease: a systematic review and meta-analysis. Endosc Int Open 2018;06:E1369-E1378.

22. Silvester JA, Faucher EA, McCarty CE, et al. Red spot lesions in the duodenal bulb are a highly specific endoscopic sign of celiac disease: A prospective study. Pediatr Gastroenterol Nutr 2019;68:251-5.

23. Aldaghi MA, Deghani SM, Haghiat M. Evaluation of the correlation between tTG-IgA titer and duodenal biopsy findings in children with suspected celiac disease. Iran J Pediatr 2016;26:e3615.

24. Chan J, Mack DR, Manuel DG, et al. Validation of an algorithm to identify children with biopsy-proven celiac disease from within health administrative data: An assessment of health services utilization patterns in Ontario, Canada. PLoS One 2017;12:e0180338. 